\title{
Determinants of Community Governance for Effective Basic Service Delivery in Nepal
}

\author{
Keshav K. Acharya
}

\begin{abstract}
Community governance is an approach of shift from governmentality to governance. This is more flexible approach extends beyond government, and the place of its agencies, to a greater sharing of power between the state, the market and civil society via new network and partnership structures. This paper analyses the determinants of community governance at the grassroots level in Nepal for the efficient delivery of basic services based on primary data sources. 110 locally constituted community based organisations were selected for an organisational survey. Additionally, three focus group discussions and 40 in-depth interviews were employed for information collection. A multiple linear regression model was used for data analysis, which revealed 12 variables such as Inclusive participation (X1), Empowerment of the people (X2), Transparency and accountability (X3) Enabling environment (X4), Practice of local democracy (X5), Service effectiveness (X6), Service integrity (X7), Social capital development (X8), Institution building (X9), Community mobilisation (X10) Planning, implementation, and monitoring (X11), Coordination, linkage, and partnership (X12) are significantly influencing governance practice. Results indicated a 14 percent variance between dependent and independent variables. This shows the overall practice of governance at the community level was malfunctioned, which can be attributed to a number of factors. First, many community-based organisations (CBOs) do not adopt governance mechanisms in their approach to development. Second,
\end{abstract}


despite a crisis in governance, some CBOs have participated in the service delivery process. Third, this crisis has been a foremost obstacle in the working culture of CBOs. This analysis further explores the problem from the perspective of socio-economic structure, power politics and interests, institutional issues, and capacity and resource constraints.

Keywords: community governance, community-based organisation, determinants, service delivery.

\section{Introduction}

In the late 1960s, many nations of the world were unable to provide the basic services due to failure of the market mechanism (Bowles \& Gintis, 2002). O'Brien and Penna (2008) refer that the institutional crises is a basic reason of market failure that causes democratic catastrophe, economic vulnerabilities, and obscure the service delivery. Pyakuryal and Suvedi (2000) describe that endogenic and exogenic factors are simultaneously responsible for the onset of poor service system in these nations. To these end, many developing nations tried to transform their policies, and legal provisions in the late 1980s towards and good governance through legislative process, as they believed governance enables broader actors such as state, market, civil society and community not only to be a part of the rules of the game, but enforce them what values are established in a society, such as justice, collective identity, belongingness, trust, and solidarity (de Souza, 2003). Nevertheless, the voices and participation of the local communities, and voiceless as well as marginal people were not properly assimilated in the existing service delivery mechanism. In these nations, governance is not functioning as art of steering to build the relationships of actors to operationalize the power and performance (Cowell \& Murdoch, 1999).

To equalize the society mainly bring the local community into development mainstreaming, evidences indicate that the present discourse of community governance has been initiated from the UK after the Second World War, where the government had focused the community level governance system in three different phases (Halsall, 2012). In 1997, the government of UK formally introduced the term of 'community governance' in the development discourse by combination of various indigenous practices, rules, norms and 


\section{8| Keshav K. Acharya}

values. Community governance is a flexible approach extends beyond government, and the place of its agencies, to a greater sharing of power between the state, the market and civil society via new network and partnership structures (Acharya, 2015). The purpose of this new discourse was to inspire the "communitarian movement" and accentuate the pluralism of power distribution within local communities and the power of associative with civil space in market-based societies (McCluskey, Stein, Boyle, and McLeod, 2009). Community governance focuses on a set of relatively stable relationships which are non-hierarchical and interdependent natures linking with varieties of actors, who share common interests with regard to a policy and who exchange resources to pursue these shared interests acknowledging that cooperation is the best way to achieve common goals (Meyer, 2007).

Nevertheless, the greater parts of the world have suffered by economic and political crises that resulted in institutional dilemma and malfunctioning of governance, such as service inefficiencies, rampant corruption, weak rule of law and excessive bureaucratic pressures (Escobar, 1988). In the 1970s, a common attempt was made through neo-liberalisation to address state failure and recover national economic growth. This encompassed free trade and open markets, privatisation, denationalisation and deregulation (Bell \& Cloke, 1989).

Conversely, the cycle was inverted during mid-1990s, which created a serious threat to neoliberalism and its control of social justice, social cohesion, and local democracy. Murray (2012) argues that the failure of neoliberalism to address the public services, community, social exclusion, and create social safety nets to the marginalised sections, gave rise to governance which explored and established the idea of a community life style. In response to this failure, policymakers, practitioners and scholars have turned towards the idea of community governance, which is an art of steering that connects multiple agencies such as state, market, civil society and people in a structured system, and builds their relationships to operationalise power and performance (Cowell \& Murdoch, 1999).

However, many authors argue that the new pattern of community governance has been fragmented by number of factors that delimit 
the efficiency of service delivery (Armstrong et al., 2005). These are: down-turning legislative framework; limited functionality for the institutional development; fragmentation in harmonised approach to local development; absence of robust transparency and accountability mechanisms; fragmented development initiatives; flawed coordination of donor, government, \& NGO local level development initiatives; limited participation of citizens in decisions; and poor information flows. Additionally, low attention of the local government to the overall welfare of the area; empowerment and access of the communities in the local government activities; appreciate the contribution of public, private and voluntary organisations; best use of the resources and address the local needs; neutrality of the local authority (Escobar, 1988).

In Nepal, the formal implementation of community governance was begun after enactment of Forestry sector Master Plan 1989 to conserve, manage, and utilise the local forest resources through specified community forestry user groups. On the other hand, many community groups, which had long engagement to the community development, were not formally regarded as vehicle of community development. Such mind setup of the government created acute risk to the community governance. In addition the prolonged reluctance of the public, inter/non-government and donor sectors in incorporating the norms of community governance in policies, acts, regulations and guidelines has been a deterrent (Bhattachan, 2002; Dahal, 2004). Experience shows that many communities have low institutional, human and material capacity to carry out their envisioned activities. The lack of skills and absence of legal authority lead unfairness, inequality, unaccountability, exclusion, and poor service delivery. Yet, some improvements in systematising community governance and its forms, categories and practices were noticeable after the 1990s, and these have been in such functions as service distribution, local resource management, economic/social empowerment, social capital building, social/public accountability, anti-discrimination programs and development management.

In such context, this paper attempts to identify the determinants of community governance for effective basic service delivery in Nepal. In the next section, some theoretical approaches are highlighted followed by another outlining the method adopted for the study. 


\section{0| Keshav K. Acharya}

Data is then analysed and the findings are presented in the third section followed by a discussion revolving around institutional issues, socio-economic structure, power politics and interests, and capacity and resource constraints.

\section{Literature Review}

Community governance is a powerful instrument of local community that has created opportunities for the involvement of broad-based community partners in the policy process through devices such as people's panels. With this belief, the community governance creates a common ground for community people and institutions through participation, building social capital, central-local relationships and connect community desired needs to recourses and services delivery mechanism (Bovaird, 2007; Gaynor \& O’Brien, 2011). Some authors (Goss, 2000; O'Toole \& Burdess, 2004) believe that community governance is an outcome of the 'minimal state' approach of the higher levels of government and the desire of local community groups to ensure a sustainable level of services for their communities.

In the governance framework, community governance focuses on leading, facilitating, collaborating and bargaining both within and without the local community (O'Toole \& Burdess, 2004). This system espouses to reduce the cost of governments for providing development assistance; government are enforced to promulgate the community driven policies (Wallace, 2012); and encourage community to shift the community from bureaucratic pathology to social cohesion (Cantle, 2005). This indicates community governance is a new 'communitarian movement' that emphasises about the pluralism of power distribution within local communities and the power of associative with civil space in market-based societies (McCluskey et al., 2009).

However, communities in developing societies are usually characterised by disorganised, disintegrated or low physical/ technical, human resource capacities, economic vulnerability, and difficulties in accessing basic services, elite control and a greater degree of exclusion (Bilsborrow et al., 1987). Consequently, these factors lead to impoverished community governance, institutional 
crises, poor governmental performance, and power arrogation and most notably rampant corruption. Commins (2007) systematically lists a range of factors that affect community governance and service delivery. These include: social, political and economic exclusion; economic differentiation; information asymmetry; and socioeconomic disparity. Some authors point out that the lack of enabling environment (legal provisions, decentralised policies and strategies, and good governance), bureaucratic complexities (power devolution, partnership development, and working in coordinative actions), confronting interests of partners, and bias are major hindrances of community governance effectiveness (Chambers, 1999; Matunhu, 2011; Ostrom, Schroeder, \& Wynne, 1993; Uphoff, 2004; Zafarullah \& Huque, 2001). Additionally, social factors mainly structural causes (exclusion, feudal legacy, exploitation, and social discrimination), modernisation (technology and globalisation), westernisation (neoliberal agendas), and marketisation (competition) are diminishing the effectiveness of community governance (Illing \& Gibson, 2007; Roodt, 1996;). Political factors, such as power structure (political and social elitism), patron-client relationships, political system, and neocolonial policies are also influencing community governance (Lewis \& Kanji, 2009; Malla, 2001). Other explanations include economic factors such as poverty and deprivation including vulnerability, seasonality, powerlessness and humiliation (Chambers, 1995); lack of skills and knowledge for optimum utilization of local resources (Oliver, 1997), unfair resource distribution, lack of fair benefit distribution and financial resources crisis are also notable factors (Mahanty, Guernier, \& Yasmi, 2009).

More recently, community governance has been influenced by innovations in technology, information and communication. Escobar (1988) identifies six factors that influence the effectiveness of community governance: changing roles and relationships between citizens and central/local government; political, economic and social empowerment agenda manipulation; access difficulties for communities to local service systems; weak technical and financial capacity of community organisations; lack of awareness and knowledge of people in governance roles; and overbearing traditional power structures of communities. 


\section{2| Keshav K. Acharya}

In addition to these explanations, other critics point out unsound state of community governance in delivering effective services in developing countries. However, many of these criticisms focus narrowly on certain particular issues, while others are too general to be linked to community concerns with governance. For example, Banner (2002) describes the disenchantment of many grassroots actors who view community governance as upwardly accountable and thus susceptible to uncertainties. In such a condition, it cannot ensure a "safety net below the safety net" as the resource crisis at the grassroots forces reliance on external actors, who are by nature more bureaucratic and prefer a hierarchical structure that has the potential to threaten the community governance system. On the contrary, Cheshire (2000) believes that central and local government commitment, engagement of the private sector, and community cooperation can help achieve community governance effectiveness. Weber et al. (2001) explain that major shifts in community governance occur as outcomes of three elements: policy discourse, policy actors, and policy instruments - all of which are influenced by events or episodes and institutional performance.

Some authors suggest that a neo-liberal agenda has often driven priorities from community-centred imperatives to those more relevant to society (Pillora and McKinlay, 2011). For this, community governance can hardly compete with the public sector and market forces. Stâhlberg (1997) argues that it has always faced problems of legitimisation and has been unable to make institutional shifts (single to multiple) or system transformation (top-down vs. bottom-up). O'Toole (2006) focuses on three internal factors: accountability of the leadership, inclusiveness and the scope of responsibility, and two external factors, relationships to the state and types of relationships with other groups, which deeply influence community governance effectiveness or its converse. Often these create hierarchical structures and empower nominated leaders rather than citizens from the process. In addition, institutional vacuums, patrimonial power structures, political and social patronage, fragmented political and bureaucratic systems, depressing economic performance, elite capture of power and resources, and centralised delivery systems impinge on community governance, diminishing social cohesion and enrich structural exclusion (Dahal, 2010; Ross and Osborne, 1999; Bardhan and Mookherjee, 2005; Grindle, 2007). 
By contrast, the effectiveness of community governance depends on efficient functioning of several variables such as inclusive participation, the empowerment agenda, the process of transparency and accountability, an enabling environment, the practice of local democracy, the service delivery system, service integrity mechanisms, social capital development, institution building tools, community mobilisation activities, planning, implementing and monitoring process, institutional schemes (both formal and informal), and coordination, linkages and partnerships between development agencies activities. These variables are the causes or agents that extend or limit the effectiveness of decisions or actions of organisations. At the grassroots level, their degree of impact may be determined by their relevancy, accuracy, credibility, quality and integrity, timeliness, coherence, accessibility and cost efficiency.

In Nepal, numerous factors have deeply affected community governance and its influences at the grassroots. These include conventional institutional arrangements, centralised decisionmaking patterns, mistrust and weak coordination among development actors (viz. central/local government and non/intra-governmental organisations), misappropriation of resources, and capture of opportunities by dominant groups at the local level (Khanal, 2006). At the community level, practices vary from one $\mathrm{CBO}$ to another or from one place to another.

\section{Methodology}

Purposely, five village development committees (VDCs) such as Goltakuri, Hekuli, Shreegaun, Shantinagar and Pawannagar VDCs at the lowest unit of local government of Dang district in Nepal were chosen for the study area that exhibits the necessary levels of rural endemic poverty and long-term marginalisation or exclusion from the basic service structures or mechanisms. Furthermore, such VDCs are located in the most remote and poverty-stricken pockets of Nepal, farthest from district headquarters and major urban centres. These remotely locations are known for the endemic poverty of their people who are consistently marginalised from basic service delivery structures. 


\section{4| Keshav K. Acharya}

There the "ultra-poor'" and poor ${ }^{2}$ households (HHs) constitute more than 56 percent of the population. Access to safe drinking water and sanitation services for these households constituted 36.32 and 41.26 percent respectively (WaterAid, 2012). The education status shows that 59.38 percent were literate. The involvement of local government bodies (LGBs), sectoral line agencies (SLAs), donors and NGOs in these localities has a long history (Figure 1)

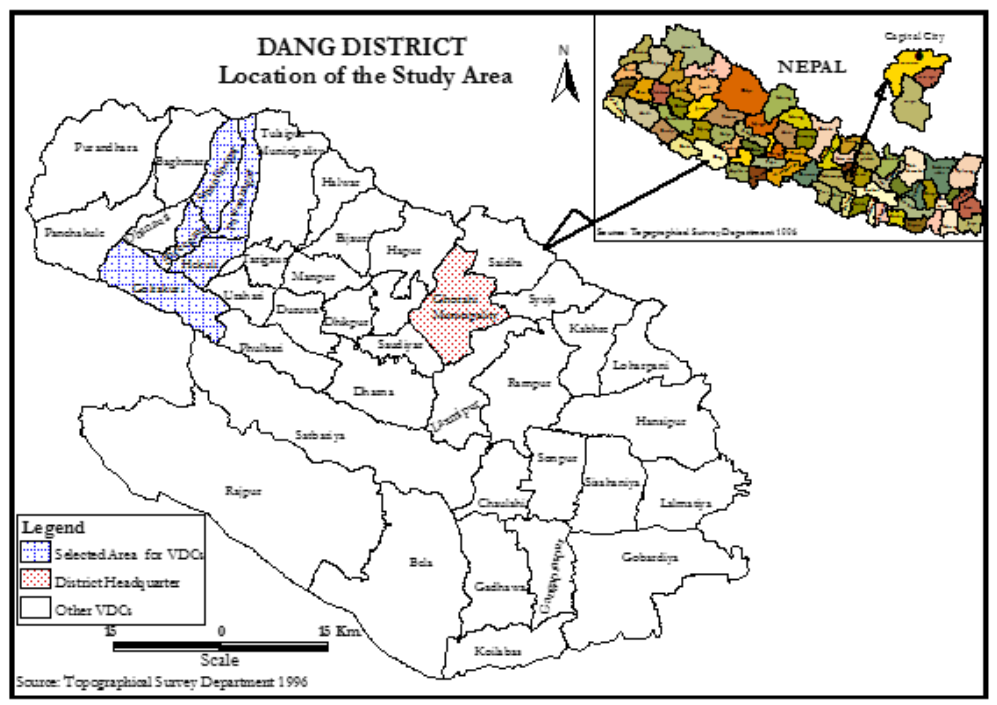

Figure 1: Location Map of the Study Area

Three broad categories of CBOs were chosen purposefully for sampling. These were Community Forestry User Groups (CFUGs), Community Development Organisation Groups (CDGOs) and Women Development Groups (WDGs). The CFUGs are directly involved in natural resourcemanagementactivities, as pergovernment regulations. Supported by local government and development partners, CODGs conduct social, economic and infrastructural

1. Ultra poor are those who do not have sufficient food for more than 3 months a year (See:http://www.pafnepal.org.np/uploads/document/file/ paf-nepal-annual-report-2013_20140309053215.pdf.

2. Poor are those who have lack sufficient resources to live at a standard considered comfortable or normal in a society. 
development activities, while WDGOs attempt to ensure women's participation and gender inclusion in local development activities at the grassroots level. As people's representatives and facilitators of local services, these bodies have been actively involved at the community level since 1990 .

Both quantitative and qualitative data were used in this study. For the quantitative data, the sampling method of Arkin and Colton (1963), was administered, with 95 percent confidence level and 5 percent precision level determined the total population comprising the study area. The proportion of population comprising the sample size was determined by, using the following formula (Yamane, 1967).

$$
\begin{gathered}
\mathrm{n}=\frac{\mathrm{N}}{1+\mathrm{Ne}^{2}} \\
=\frac{152}{1+152 \times 0.05^{2}}
\end{gathered}
$$

Similarly, the number constituting the sample size was determined by following formula:

Sample Size

$$
\text { Sample Fraction }=\longleftarrow \times \quad \begin{aligned}
& \text { Individual } \\
& \text { Population of } \\
& \text { Organisations }
\end{aligned}
$$

Total Population of

Respondents

Table 1: Sample size for the grassroots level organisational survey Description/Type of Organisations Total No. of Sample No. Groups

\begin{tabular}{lcc}
\hline Community Forest User Groups (CFUGs) & 44 & 31 \\
Community Organisation Groups (COGs) & 72 & 53 \\
Women's Development Groups (WDGs) & 36 & 26 \\
\hline Total & 152 & 110
\end{tabular}

110 organisational surveys were administered based on simple random sampling. The respondents were the chairpersons and 


\section{6| Keshav K. Acharya}

secretaries of the selected organisations and closed ended structured and multiple choice questionnaires were employed for gathering data. Similarly, three focus group discussions (FGD) sessions were organised to bring live experiences from the field. From the FGDs, governance patterns and the nature of public access to basic services were discerned. However, it was confirmed the research ethics standards, as set out in the guidelines for Human Research Ethics at the University of New England to employ the primary data collection. The researcher gained approval for all components of the research: the organizational survey and focus group discussion.

At the community level, a number of micro-level variables are important in analyzing governance efficiency and determining the effectiveness of the basic service delivery system. For this, a number of dependent and independent variables were set. The dependent variable (Y) assigned on the basis of main objective of the study, related to the deployment of community governance in service delivery. To determine the relationships, the following independent variables were selected (Table 2).

Table 2: Identification of independent variables

\begin{tabular}{ll}
\hline Variables & Specification \\
\hline & -Equal benefit sharing \\
& -Leadership selection \\
Inclusive participation $\left(\mathrm{X}_{1}\right)$ & -Resource mobilisation and management \\
& $\begin{array}{l}\text { Decision making } \\
\text {-Access to executive committees }\end{array}$ \\
\hline Empowerment of the & -Social empowerment \\
people & -Political empowerment \\
& -Economic empowerment \\
$\left(\mathrm{X}_{2}\right)$ & -Organisational change \\
& -Community Transformation \\
& -Establishment of social intelligence \\
Transparency and ac- & system \\
countability $\left(\mathrm{X}_{3}\right)$ & -Completion of financial audit system \\
& -Information and communication flow \\
& -Conduct public and social audit \\
& -Regular assembly meeting \\
\hline
\end{tabular}




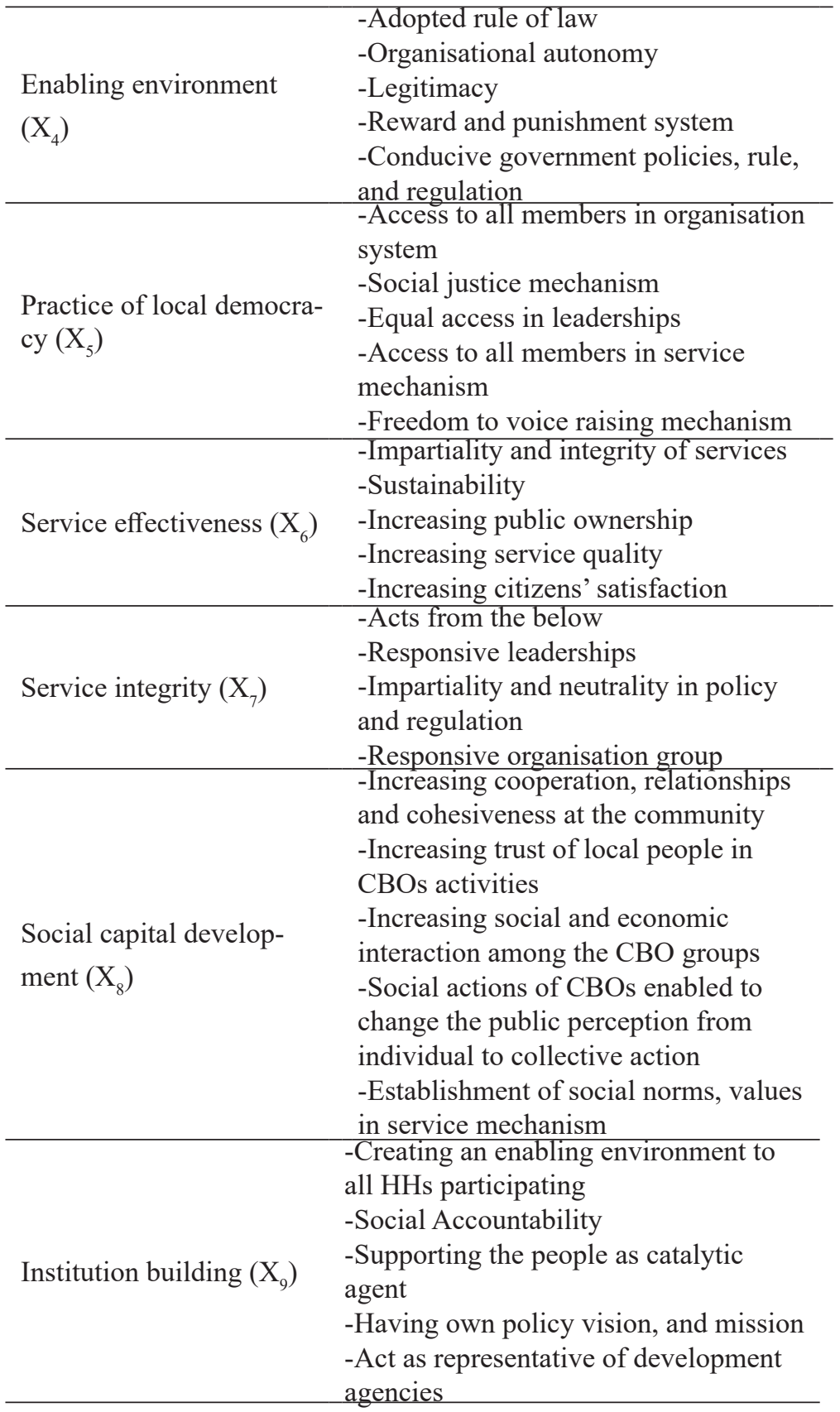




\begin{tabular}{ll}
\hline & -Institutionalise participatory bottom- \\
& up \\
& process in CBOs actions \\
& -Economic resource mobilisation \\
& activities \\
& -Community empowerment activities \\
& Transparency and accountability in the \\
& actions \\
& -Minimising the role of political and \\
& feudal elites in the community power \\
& Structure \\
\hline & -lnstitutionalise the participatory \\
& planning and monitoring process \\
& -Projects selection is based on demand \\
& driven at the settlements level \\
& -Community services are owned and \\
& managed by local people \\
Planning, implemen- & -Members participation in planning, \\
tation, and monitoring & implementation and monitoring process \\
$\left(\mathrm{X}_{11}\right)$ & -Self-public contribution for the \\
& services as per the provision \\
\hline & -Coordination with local government \\
& -Coordination with other sectoral line \\
& agencies \\
Coordination, linkage, & -Coordination with civil society, NGOs \\
and partnership $\left(\mathrm{X}_{12}\right)$ & and INGOs \\
& -Involvement in networking forums \\
& -Partnerships with private sectors in \\
& community development activities \\
\hline &
\end{tabular}

\section{Findings And Results}

To identify the effectiveness of community governance, a multiple linear regression model was administered to analyse the inducing factors influencing the effectiveness of service delivery. Community governance effectiveness was identified by the dependent variable (Y). This was affected by different sets of independent variables (X1...., X12). The variables were further analysed using stepwise multiple linear regression. The dependent variables were considered as a numerical index which was assumed to vary from one organisation to another. 
To execute the multiple regression analysis, the dependent variable governance for the effective service delivery, was assumed as being controlled by the number of independent variables: $\mathrm{X} 1, \ldots, \mathrm{Xn}$. The specified model is as follows:

$$
Y=b 0+b 1 X 1+b 2 X 2+\ldots \ldots \ldots .+b n X n \text {; }
$$

Where, $\mathrm{Y}=$ dependent variable of governance practice, $\mathrm{b} 0=$ intercept, $\mathrm{b} 1, \mathrm{~b} 2, \ldots, \mathrm{bn}=$ coeffcients of explanatory variables $\mathrm{X} 1, \mathrm{X} 2, \ldots, \mathrm{Xn}$. The model was constructed using the backward probability criteria of $F$ to enter $<=0: 050$, and probability of $F$ to remove $>=0: 100$. Independent variables $(\mathrm{X} 1, \ldots, \mathrm{X} 26)$ entered in the analysis were not significant for deletion.

Similarly, the ANOVA (analysis of variance) was employed to calculate the consisting variability levels within a regression model. From the basis of significance test, the variance of the independent variables was determined. For analysing focus group discussions, the acquired data were transcribed and coded according to thematic issues, such as role of CBOs in practicing community governance, and inducing factors of governance. Later the coded data was analysed according to each theme.

The relationship between independent and dependent variables shows when one variable causes a change in another variable. For the relationships of the variables, two types of relationships (positive and negative) were established. However, the significant relationships were measured if the chances of observing the relationship were stronger than 95 percent. Table 3 shows the results of inter-correlations of all predictor variables and presents the positive inter-correlation between dependent and independent variables. 
180| Keshav K. Acharya

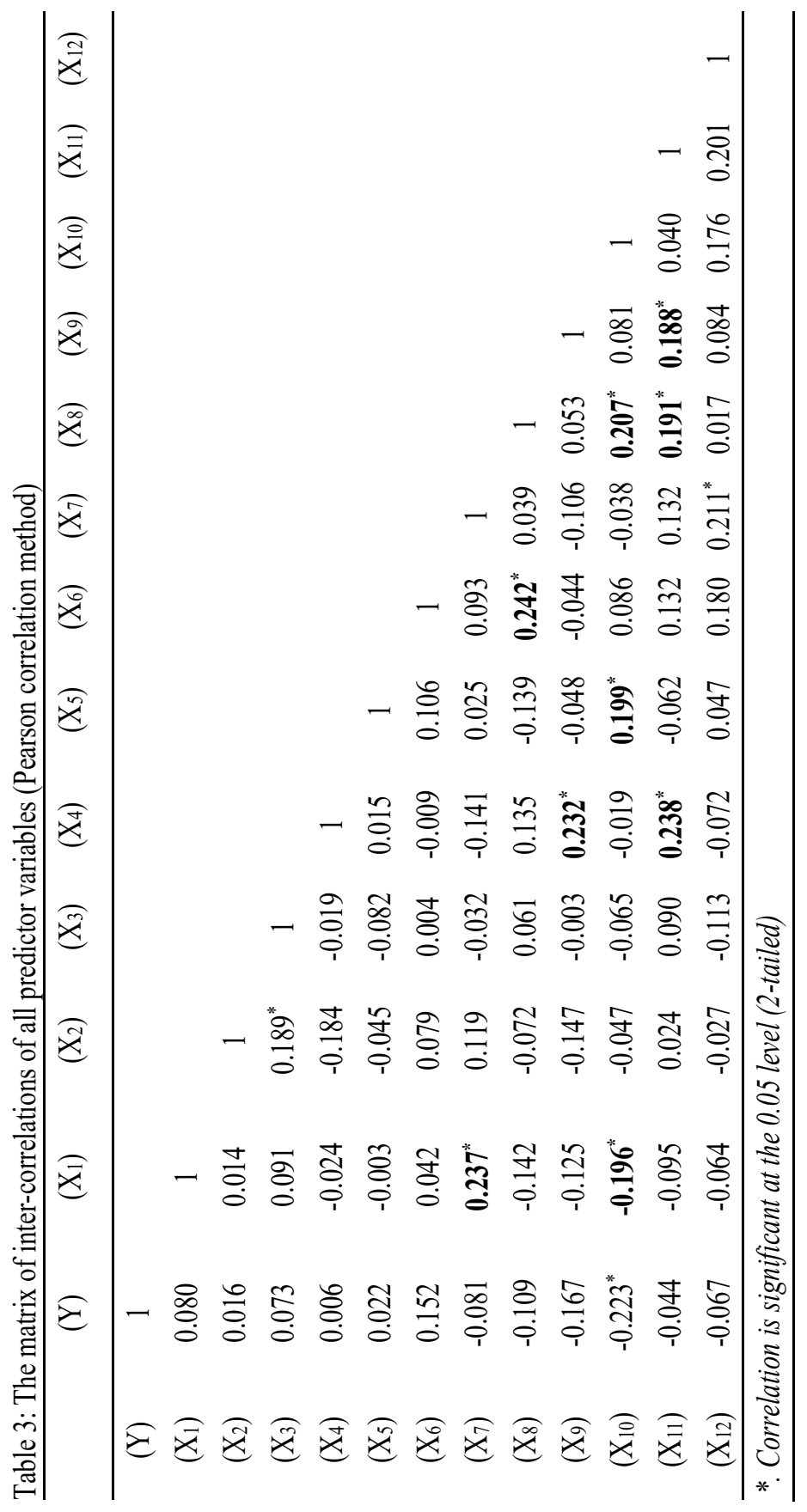


The result shows positive correlation of community governance with inclusive participation (X1), empowerment (X2), transparency and accountability (X3), enabling environment (X4), local democracy (X5), and service effectiveness (X6). This indicates that the CBOs are very conscious of the need to achieve positive outcomes in these areas. However, such variables remained only positive correlation not comprised any significant correlation result. This indicates more effort is still required to reinforce the community governance.

By contrast, a negative inter-correlation of governance with six other determinants, namely service integrity (X7), social capital (X8), institution building (X9), community mobilisation (X10), planning, implementation and monitoring (X11), and coordination, linkage, partnership development (X12) was discerned. Among them, significant negative correlation with community mobilisation activities (X10) was found. Poor recognition of governance concepts and absence of best practice, lack of autonomy in CBO operations, absence of transparency in project implementation, poor social accountability, unreasonable public hearings, social audits and citizen report cards, elite-based community power structure, little concern for the poor and remote areas, and doubtful records, agenda and documentation contributed to the ineffectiveness of community governance. Empirical information indicates that negative correlation was the outcome of ill-feeling, frustration and dissatisfaction within communities, CBO structural problems such as upward accountability, and their dependence on government and donor agencies. These practices affected community-owned indigenous practices, cooperation and collaboration, community existence, and communitarian values.

In Nepal, the Acts, regulations, and policies are not inclusive: not only do they fail to transfer power to the local level, but they also entrench the centre's political interests in the name of decentralization. Experience reveals that the complexities of these legal procedures strengthened the centralization process and increased the influence of political and local elites in the community power structure and local resource mobilisation. Table 2 shows the matrix of intercorrelations of all predictor variables (Pearson correlation method). Prediction of the model 


\section{2| Keshav K. Acharya}

To examine the relationship between two or more independent variables (X) and a dependent variable (Y), a multiple linear regression model was employed, by fitting a linear equation to experimental figures. In this model, each value of the independent variables is related with a value of the dependent variable. Table 4 presents the relationships between the dependent and independent variables in governance effectiveness applying a regression analysis model.

Table 4: Summary of the model

Std. Error of

\begin{tabular}{ccccc} 
Model & $\mathrm{R}$ & $(\mathrm{R})^{2}$ & Adjusted $(\mathrm{R})^{2}$ & the Estimate \\
\hline 1 & $0.381^{\mathrm{a}}$ & 0.145 & 0.012 & 0.688 \\
\hline 2 & $0.381^{\mathrm{b}}$ & 0.145 & 0.025 & 0.683 \\
\hline 3 & $0.381^{\mathrm{c}}$ & 0.145 & 0.037 & 0.679 \\
\hline 4 & $0.380^{\mathrm{d}}$ & 0.144 & 0.048 & 0.675 \\
\hline 5 & $0.378^{\mathrm{e}}$ & 0.143 & 0.058 & 0.672 \\
\hline 6 & $0.376^{\mathrm{f}}$ & 0.141 & 0.068 & 0.668 \\
\hline 7 & $0.373^{\mathrm{g}}$ & 0.139 & 0.077 & 0.665 \\
\hline 8 & $0.371^{\mathrm{h}}$ & 0.138 & 0.086 & 0.662 \\
\hline 9 & $0.363^{\mathrm{i}}$ & 0.132 & 0.091 & 0.660 \\
\hline 10 & $0.330^{\mathrm{j}}$ & 0.109 & 0.078 & 0.665 \\
\hline 11 & $0.292^{\mathrm{k}}$ & 0.085 & 0.064 & 0.669 \\
\hline 12 & $0.247^{\mathrm{l}}$ & 0.061 & 0.051 & 0.674 \\
\hline & & & &
\end{tabular}

According to Table 4, R (correlation coefficient) denotes the degree of relationship between twelve independent variables, and the dependent variable through multiple regression analysis. It shows the unadjusted multiple $\mathrm{R}$ as 0.381 and the unadjusted value of (R)2 as 0.145 . This indicates a 14 percent variance of the dependent variable. Similarly, the figure of adjusted (R)2 of 0.012 shows there was a greater difference between (R)2 and adjusted (R)2, which was less than 1. Table 3 further indicates that both $R$ and (R)2 values increased from X12 to X1. This shows that the functional results of variables were statistically significant and all variables indicated their reasonable descriptive control in the models. Induced from the sets of factors, the overall result shows the practice of governance at the community level to be very poor. Table 4 shows the ANOVA (analysis of variance) test to calculate the variability levels within a regression model and explains the regression and residual analysis of different properties. 
Dhaulagiri Journal of Sociology and Anthropology Vol. 10, $2016 \mid 183$

Table 5: ANOVA of the regression model

\begin{tabular}{cccccc}
\hline Model & $\begin{array}{c}\text { Sum of } \\
\text { Squares }\end{array}$ & $\begin{array}{c}\text { Degree of } \\
\text { Freedom }\end{array}$ & $\begin{array}{c}\text { Mean Square } \\
\text { Regression }\end{array}$ & F- ratio & $\begin{array}{c}\text { Signifi- } \\
\text { cance }(P)\end{array}$ \\
\hline Regression & 6.198 & 12 & 0.517 & 1.092 & $0.379^{\mathrm{a}}$ \\
\hline Residual & 36.424 & 77 & 0.473 & & \\
\hline Total & 42.622 & 89 & & & \\
\hline
\end{tabular}

The residual is the difference between the observed value of the predicted value (the residual) and the dependent variable. If the sum of the residuals is greater than 0 , the data set is non-linear, which supports the non-linear random pattern of residuals model. According to the results the residual for the sum of square (SS) is 36.424, which represents a non-linear random pattern. This illustrates the practices and effectiveness of the CBOs are failure to deliver the community basic services. Healey (2011, p. 214) explains that "the degree of freedom corresponds to the number of coefficients estimated minus 1". Table 4 shows 13 coefficients (dependent and independent variables) in which the model remains 13-1=12 degrees of freedom. The error in the degree of freedom is 77 (The DF total minus the DF model, 89-12=77). The Sig. value is greater than 0.05 in each coefficient. This indicates there is a statistically significant difference between variables.

The P-value is normally compared to the alpha $(\alpha)$ level ( $\alpha$ remains 0.05). Berenson and Levine (1998, p. 394) illustrate that "If the $\mathrm{P}$-value is greater than or equal to $\alpha$, the null hypothesis is not rejected whereas, if the P-value is smaller than $\alpha$, the null hypothesis is rejected." Hence the hypothesis 'practice of community governance' is highly influenced by set of independent variables. Table 6 indicates that the P-value is greater than $\alpha$ level, which means the independent variables were reliably predicted to the dependent variable. 
184| Keshav K. Acharya

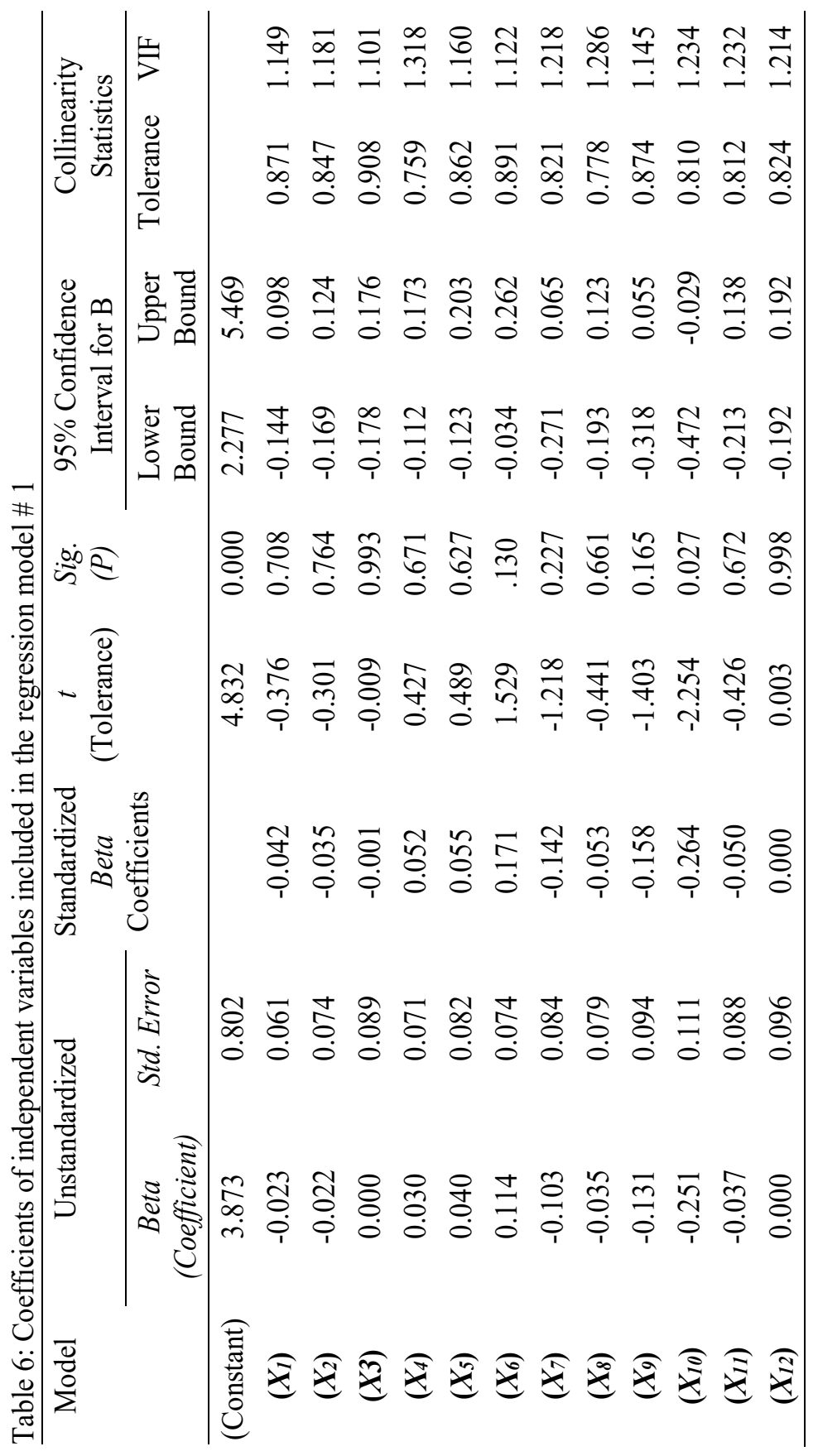


According to Table 5 the beta coefficient shows there was a positive relationship between the dependent variable and the independent variables, such as in the cases of enabling environment (X4), practice of local democracy (X5) and service effectiveness (X6), whereas there were negative relationships for inclusive participation (X1), empowerment of people (X2), service integrity (X7), social capital development (X8), institution building (X9), community mobilisation (X10), and planning, implementation, monitoring and evaluation system (X11). No relationship was found with transparency and accountability (X3) and coordination, linkage, partnership development (X12).

The unstandardized Beta-coefficient shows the overall relationships between dependent and independent variables as positive $(\mathrm{B}=$ $3.873)$, whereas the individual relationship varied. For the models $1,2,7,8,9,10$, and 11 , the coefficient was negative. So, for every unit increase in these models, the dependent variable was predicted to be lower in the same units. This was significantly different to 0 . Similarly, models 4,5 , and 6 , the coefficient (parameter estimate) was positive, which indicates that for every unit increase in these models, the dependent variable was predicted to be higher in the same units. Likewise, model 12 had no relationships.

Based on these realities, the crisis of governance at the community level could be grouped into three possible practical variations. First, many CBOs did not adopt governance indicators in their development initiatives. Second, despite the presence of a governance crisis, some CBOs are engaged in the service delivery system. Thirdly, a governance crisis has been a major obstacle in the working culture of CBOs. To end these problems, it was crucial that a number of reforms were introduced to revitalise the delivery capacity and quality of governance at the community level.

The above analysis indicates that service delivery and governance at the community level in Nepal is weak, unaccountable and unresponsive. The lack of political and bureaucratic commitment, over-regulatory and non-professional bureaucracy, and ineffective rule of law, rampant corruption, weakened accountability and sluggish economic growth imparted more benefits of neoliberalism to the rural elites. With better access to education, communication and 


\section{6| Keshav K. Acharya}

information, they built their own capacity in capturing the services meant for the people. These issues served to deter the community from actively engaging in community governance matters.

\section{Discussions}

Despite many efforts to reinforce the community governance in Nepal, numerous factors are still essential for compliance with the governance variables. Empirical findings point out that CBOs faced many constraints at the local level: inadequate resources, scarcity of knowledge and skills, absence of legitimisation, and an unsupportive enabling environment (policy and legal arrangements), which undermined their capability. These factors contributed in a negative manner on the levels of effectiveness of community governance.

\section{Impaired institutional mechanism}

The formal institutional mechanism at the grassroots level in Nepal is profoundly impaired due to the elite dominancy, attitudinal deficiency, depletion of commitment, and prematurity in policy formulation. In Nepal, local elites are an inbuilt system of the society as their major roles regarded with power structure and less attention to legitimised system of the community participation. They captured all possible alternatives and created a monopoly in the service mechanism. These types of protagonists were not only hindrance of the local institutions and communities for project selection, implementation and harnessing of resources, but also causing to destroy public motivation in institutional development. At the grassroots level, most of the resourceful CBOs, such as community forestry user groups, mother groups, school management committees, and drinking water consumer committees were captured by the elites. In these projects, elite domination occurred in four stages. First, their entry was as facilitators, supporters and enablers. They intentionally involved themselves in the people's institutions. Second, they gradually captured the groups' social capital and decision-making processes. Third, they began to capture the physical assets, particularly natural resources, cooperative-generated finances and government and donor funds. Finally, they utilised these for their political benefit. This cycle of events was the prime reason for the poor institutional mechanism that undermined the community governance process. 
In addition, the attitudinal crisis and facility-oriented mentality of the development agencies, and other motivational factors limited service access in remote areas. The closely bonded relationship developed between service actors (state and non-state) and local elites captured the services and made them less accessible, more complex and badly compromised in terms of quality. This collusion created a scarcity of resources and a problem in accessibility for the poor and marginal groups. Thus, the delivery of services in these areas, and the formulation and preservation of voluntary community organisations, became a bigger challenge for community governance. Additionally, some other factors contributed to this chaotic situation and made the people's institutions ineffectual. First, the isolated actions of the government and lack of incentive of non-government sectors discouraged indigenous community governance practices. Only certain sectors and classes, at the expense of the larger sections of the population, benefited. Secondly, it promoted a dependency syndrome. For example, community dependency on leadership and the latter's on the developing agencies, caused institutional decay and dysfunctionality, and inclined the leadership towards corruption.

Post-1990, the new democratic government reformed many policies under the framework of neoliberalism to enhance the privatisation, denationalisation and deregulation. To enable this development, local governments (LGs) were upgraded to 'development coordinators' at the intermediate and grassroots level. However, unstructured and insufficient policy guidelines of local government failed to meet the national interest in governance. Experiences indicate that such guidelines were not only politicised, but also converted local government into a regulative institution of the central government. Consequently, these institutions became more bureaucratic, lethargic and unaccountable. Similarly, grassroots organisations were politicised as they did not pay attention to the members' interests, grumblings and grievances, or follow the institutional rules and regulations. Most of the CBO groups' activities lacked documentation. They were reluctant to uphold group policies, rule and regulations or had no policies and programs; they bypassed a public auditing and public hearing system, regular group meetings, and neglected the people's participation. 


\section{8| Keshav K. Acharya}

Matunhu (2011) argues that the major deficiency in developing countries is the absence of a clear policy framework and the commitment to implement this. This makes for community difficulties in accessing services. At the same time, government bureaucrats, donor technocrats, and political elites often undermine community participation and their institutional roles in participatory development. Despite such realities, the social mobilisation approach helped transform rural livelihoods through improved community health and sanitation conditions that lowered the maternal and child mortality rate, increased school enrolments and improved access to market facilities for agricultural products, reduced influence of middle-men in determining the prices of commodities, and produced an increased annual per family income. However, ambiguous agreements between the government and donors, an inequitable policy for group formalisation, inappropriate power devolution, autonomy, and the legitimisation process contributed much unevenness in $\mathrm{CBO}$ groups.

After the enactment of Local Self Governance Act (LSGA) in 1999, the participatory development process enriched the delivery system to some degree. However, due to the excessive influence of local political actors, there could be no miraculous change at the community level. By contrast, the participatory development effort became a bargaining instrument for political leaders and a means of building relationships and attracting donor programs, with which to line their pockets. Nevertheless, many communities whatsoever their institutionalisation process is formally or informally instituted, their contribution was incredibly noteworthy in community selfreliance process.

\section{Complex socio-economic structure}

Social factors such as attitude, legacy, ethnicity, family status, economic class, and awareness level and locality play a key role in effective community governance. Social structure is one of the key knights of community; it was constituted in three dimensions. First, it instituted the caste system which governs people's attitude, culture and social stratification. Secondly, community was ruled by the patrimonial system, which is related to legacy, culture and practices. Thirdly, social values were dominated by materialism. This 
stratified complete communities and affected people's confidence, relationships and practices.

Many experiences show that social structure legitimises the social organisation. However, three distinct characteristics - patron-client relationships, structural legacy, and social and economic exclusion contribute directly to poor community governance. The prime reasons were that $\mathrm{CBOs}$ were influenced by the hierarchy, local power structure, resource politics, and donors' intentions. This had not only created ambiguities for $\mathrm{CBO}$, but also encouraged the elites to jeopardise the community governance. Some examples found that senior positions in the groups were captured by Jamindar (feudal elites). They were not conscious about community voices and did not inform them about major decisions, and financial transactions. Similarly, they did not distribute benefits, and other opportunities, equally among all members.

Upreti and Müller-Böker (2010) report that these sorts of practices are part of the structural legacy of the feudal system that led weaker segments of society to lose interest in local democracy, governance, and the effective implementation of programs and actions. Although the provision of Nepalese Constitution of 2007 provided democracy for all diverse groups and channels to express their views openly, as well as to declare their identities and rights as citizens, leadership has remained largely confined to males and the so-called higher castes in society. Many participants stated that democratic practice at the community level had ceased to be inclusive. There were several reasons for this. First, the people themselves were not ready to participate in this process due to their lack of awareness and inadequate orientation. Secondly, conspiracies and unfair actions of the political parties and development partners deflated less powerful sectors of communities. Thirdly, the decentralisation of policy formulation and reformulation process from central to local was very technocratic, mechanised and overly formalised. Fourthly, CBO groups were less capable. The reforms which were introduced invariably functioned in a 'trickle down' manner, leading to a win or lose situation at the community level. This situation only enabled people with a voice, power, and wealth who could articulate the issues and convince the development partners, so that they could get the chance to participate in different groups' activities and benefit 


\section{0| Keshav K. Acharya}

from them. Young (1993) argues that this practice excludes many community members and organisations from the community building system, democratic practice, and overall governance process.

\section{Power, politics and interest}

At the grassroots level, CBOs have played a crucial role in transforming power relations and addressing community needs since historic periods. Despite such realisms, many executive leadership and key members of the CBOs were politically connected, or their actions were intricately associated with individual interests and hidden agendas. These vested interests meant that they no longer acted as agents of social change, but rather as politically motivated actors, which encouraged patronising, exclusionary and particularistic systems. Empirical evidence also points out that most of CBO leaders did not share a common interest with the general members, nor a common vision or objective. Such characteristics were facilitated by political and feudal groups, who were normally represented as middle class Tatha Bathas (social elite) families. They restricted the participation of poor Dalits and Tharus in executive positions and decision making. Titeca (2006) argues that such actions resulted in CBOs being less inclusive and power retaining attitude. This caused the decay of community governance, democracy and empowerment agendas and eroded the social cohesiveness at the community level. These impositions created undue hurdles and unnecessary pressures for the community to move away from community-owned indigenous system to a forced and fabricated framework. The empirical findings further indicate that the pre-conditions of development agencies for matching funds, the formulation of parallel institutions, and denial of the existent coordination and levels of governance, led to the decline of community interest in their institutions, as well as their participation in planning and implementation. This created many distortions and institutional deficiencies at the community level and increased the dependency of communities in the long term. This dependency meant that while CBO groups became dependent on supporting agencies and their resources, members received the tag of a single agency. The explanations of general members show that this type of affiliation was of value to the leadership, whereas the general members received minimal benefit from the service opportunities. Similarly, many developing agencies encouraged the 
people to be part of community program and supported all kinds of public demands and addressed community needs. While doing this, however, they discouraged the community from building relationships with other developing agencies. This developing agency behaviour not only disrupted coordination and linkages in development, but agencies had no means to contact one another and had no capacity to continue current endeavours.

Likewise, there were several areas of conflict of interest between general members and the executive board, which destroyed community governance and institutional efficiency at the community level. According to empirical evidence, the reasons for these conflicts of interest centred on resources and their mobilisation, skills and knowledge, project selection and implementation, and leadership. This process hindered community members' ability to organise and they had difficulty in actively involving themselves in identification of problems, planning, decision making and action, to meet their needs and resources, with or without support of government or NGOs.

In contrast, some believe that service delivery is the prime responsibility of the government and its functionaries. The people thought the government could, or should, deliver basic services such as basic infrastructure and social and physical amenities to the communities. However, government functionaries advocated that the state has devolved many powers, functions and resources to the community level. They further claimed that communities were not sufficiently self-oriented, and that CBOs were not fully capable of receiving this power and authority. Hence most of the powers, authorities and resources were captured by the local elites. At the same time, government staffs were unresponsive and behaved as adversaries of the people, keeping the political elites in the centre and the people on the periphery. They thought that only politicians and elites could maintain power at the community level through their hierarchical connections. More important, their negative attitude suggested that community demands were unnecessarily complex and a burden.

These attitudes created serious issues at the grassroots level in Nepal and caused disputes among the service organisations, which 


\section{2| Keshav K. Acharya}

appeared to show no interest in cooperating or forming linkages. There was no strategic alliance established among the development agencies, nor the development of a structured framework of CBO groups to mobilise the service functions.

Similarly, there has been a serious absence of local authority in local government for more than a decade. This vacuum has led to the misuse and misallocation of development resources, and misguided community governance, democratic practices and leadership of the local bodies, at the grassroots level. CBOs became regarded as the best institutional instrument, to fill the decision making and implementation gap at the grassroots level. However, their lack of capacity, cultural engagement with the external powers, resource constraints, and conflict of sectoral interests, led to inefficient operations. At the same time, the government decided to form the all-party mechanism as an interim arrangement to fill this vacuum, and carry on service delivery and development work at the local government level. However, the trend shows that existing political mechanisms were not only unaccountable and impenetrable by the people, but that they also encouraged unprecedented corruption and irregularities in local bodies. This behaviour encouraged partiality and exclusion at the community level.

These actions of the government created manifold difficulties and challenges for CBO groups, especially those that were marginalised. Thus, the continued absence of elected leadership jeopardised community governance at the grassroots, and as a consequence of reduced social accountability, further exposed public funds to misuse and corruption.

\section{Capacity constraints}

As was the case in other developing countries, communities in Nepal faced several constraints in accessing education, health, mobility, safe drinking water, and other essential services due to poverty, and many community organisations faced difficulties in providing these basic services. In order to address this, service organisations gave priority to enhancing the managerial and organisational capacities of local institutions through effective governance. In Nepal, the government has adopted a 'participatory' approach since the Eighth Five Year 
Plan (1992-1997), which enlisted the people's participation in the process of service delivery (Pandit et al., 2007). This broadened the scope of CBOs as the major instrument for service delivery at the community level.

Nevertheless, CBOs were unable in many cases to prove their honesty and efficiency in effective service delivery and execution of service functions. For example, the government has annually increased the volume of grants for local development, in which local bodies are recognised as development coordinators for program formulation and resource delivery. However, lack of capacity and the powerful influence of political parties meant that the local bodies were unable to reach the community itself, or manage resources in a satisfactory way. At the same time, communities themselves were not identifying problems, managing and utilising the budgetary allocations, and presenting positive results.

The findings further show the lack of CBO ability in facilitation, interaction and communication. This had several implications for the community regarding their access to basic services. Firstly, there was a greater inequity in sharing the benefits; there were great differences in the amount of time it took to form the various CBO groups. Some were constituted almost immediately, but others took years. Most CBOs were categorised as founder members or new members, based on their entry. The founder members usually received more opportunities, while new members received the minimum. In this respect, $\mathrm{CBOs}$ failed to support all members equally.

Secondly, the LSGA provisioned 33 percent women's and 10 percent Dalit and ethnic minority participation in decision making. An allocation of 10 percent of resources for women's welfare programs, and another 10 percent for Dalit and ethnic groups, from the local government and sectoral line agencies' annual budget was provided for. Owing to a lack of capacity and awareness in proposal submission, project identification and cost estimation, these groups' participation was not effective and resources were not managed efficiently, which led these resources ending up in the hands of the elites. 


\section{4| Keshav K. Acharya}

Thirdly, the rural areas were most in need of infrastructure and rural communities demanded that infrastructure projects receive priority. However, when the resources to implement the projects arrived, many groups, as well as members, did not have the vision or confidence to drive the projects. The outcome of this was that many local elites took decisions to manage projects, on behalf of the communities. Fourthly, most of the leadership positions in the groups were occupied by school teachers, former local government leaders, unemployed educated youths and the rural feudal elite. There were many instances of these elites grabbing benefits meant for the illiterate, or those lacking an understanding of their entitlements, as the former made the CFUGs more bureaucratic, centralised and elitist guided, for this purpose. Further, the elites, who grabbed power and resources, lacked the knowledge and information necessary for innovation, which forced them to depend on the District Forest Office and federation of forest users, and thus they limited themselves to sectoral agendas or political issues.

\section{Resources insufficiency}

Most of the CBOs at the community level faced a scarcity of resources, which made them more dependent on government organisations or outsiders, particularly donors and NGOs. These organisations and their officials generally displayed a paternalistic attitude, which ignored the democratic process and full participation of communities. Experiences point out that they not only rejected the participatory decision making system in their support system, but also imposed a dependency in BSDS. Malla (2001) argues that this attitude created domination and a patronising client relationship in decision making, and manipulated information and communication that deprived classes of their access to services.

In order to deliver equitable services to a community, it is imperative to allocate the necessary physical assets or funding resources, required to improve the service system and encourage public participation. Like other developing countries, community service delivery in Nepal was the responsibility of central governments, community organisations or private enterprises. This was insufficient, ineffective and sporadic, due to the top-down approach of central government or the profit-oriented motives of $\mathrm{CBOs}$ and 
the private sector. However, some examples show that multi-actor collaborations made significant improvements on the CBOs' lack of incentives, inadequate funds and absence of technical expertise. This helped address the issue of the government's reluctance and lack of awareness and coordination, in the community service system in poor areas

Apart from these problems, the legitimisation process provides a significant starting point for the institutionalisation of CBO groups, so that they can receive the resources and establish partnerships with development agencies. Experiences indicate that legitimisation of CBOs was not only a process for legal recognition, but also the instrument for social accountability, institutional capability and guarantee of resources. The absence of formal legitimacy of the CBOs meant they did not receive any funding support from the sectoral line agencies.

Some experiences demonstrate that the partnerships between resource agencies and $\mathrm{CBOs}$, in many cases, brought much prosperity and resolved many uncertainties. For example, the partnership with communities for school management, drinking water supply schemes, irrigation projects, and the number of public-private partnership projects for forest products and agricultural products such as ginger production were all able to mobilise local resources at the community level. Although these projects enabled the local communities and their institutions to make themselves self-reliant, the imperfect market network, influence of elites and middle-men, as well as technical and financial constraints, still created problems at the community level.

In late 2000, the government promoted an approach of 'sectoral devolution' for agriculture, livestock, education, health and postal service, to increase the communities' stake, improve service delivery and enhance community governance at the grassroots level, and thus fill the gap between communities and their practice of democracy. At the same time, the government encouraged the people, mainly from the marginal sectors and community based institutions, to become involved in the policy design process, through a range of planned mechanisms such as participatory planning, implementation and monitoring. This indicates that government priority was to 


\section{6| Keshav K. Acharya}

encourage the local communities in identifying needs, formulating plans and programs and implementing them; to provide accessibility, sustainability and ownership, in terms of the service delivery mechanism. However, lack of resource allocation to community projects from the central government, and political influence in local government, resulted in a low level of trust in local communities.

\section{Conclusions}

Community governance in Nepal has not only been involved in maintaining democratic practice and public access to the basic service delivery system, but also in empowering communities to ensure sustainable service delivery. Although many groups at the community level have been engaged in multi-layer matters, the trend shows that many micro and macro level factors are causing their passage from specific to polycentric issues. The results of negative inter-correlation with six variables indicate structural problems faced by CBOs such as upward accountability, inordinate dependency on others (viz. local elites, government and donor agencies), institutional crisis, socio-economic hierarchical rigidity in communities, resource misuse and service delivery manipulation. These affected the effectiveness of CG in many ways. First, lack of awareness and inadequate orientation discouraging communities from participating in community affairs. Secondly, development partners acting unfairly insofar community matters are concerned. Thirdly, the policy formulation and reformulation process being overly technocratic mechanized and formalized. Fourthly, CBO groups demonstrating limited capability. And, last but not least, group leaders being politically connected or their actions intricately associated with individual interests or hidden agendas.

Post 1990, the government transformed local government institutions into development coordinating mechanisms at the intermediate and grassroots level. LSGA and the Good Governance Act of 2006 support the objectives, policies, and principles of the existing local self-governance system through the mobilization of local communities. However, evidence indicates that CBOs are directly induced by many factors such as institutional policies, socioeconomic structure, power politics and interest, capacity constraint in community organizations, and resource constraints in community 
Dhaulagiri Journal of Sociology and Anthropology Vol. 10, $2016 \mid 197$

organizations. These create complexities in decision-making and have the potential to make them less capable and more disorganized. The basic service delivery system thereby suffers.

\section{References}

Acharya, K. K. (2015). Community governance and peacebuilding in Nepal. Rural Society. 24(1), 65-84.

Banner, G. (2002). Community governance and the new centrallocal relationship. International Social Science Journal, 54: 217-231.

Bardhan, P., \& Mookherjee, D. (2005). 'Decentralizing antipoverty program delivery in developing countries'. Journal of Public Economics, 89(4), 675-704.

Bell, P., \& Cloke, P. (1989). The changing relationship between the private and public sectors: Privatisation and rural Britain. Journal of Rural Studies, 5(1), 1-15.

Berenson, M. L., \& Levine, D. M. (1998). Basic business statistics: Concepts and applications (6th Ed.). New Jersey: Prentice Hall.

Bhattachan, K. B. (2002). Traditional local governance in Nepal. Paper presented at the national seminar on strengthening decentralization and good governance in Nepal, April 21, Kathmandu.

Bilsborrow, R. E., McDevitt, T. M., Kossoudji, S., \& Fuller, R. (1987). The impact of origin community characteristics on ruralurban out-migration in a developing country. Demography, 24(2), 191-210.

Bovaird, T. (2007). Beyond engagement and participation: User and community coproduction of public services. Public Administration Review, 67(5), 846-860.

Cantle, T. (2005). Community cohesion: A new framework for race and diversity. Basingstoke: Palgrave Macmillan.

Cheshire, L. (2000). Contemporary strategies for rural community development in Australia: a governmentality perspective. Journal of Rural Studies, 16(2): 203-215.

Clarke, M. \& Stewart, J. (1994). The local authority and the new 
community governance. Regional Studies, 28(2): 201-209.

Commins, S. (2007). Community participation in service delivery and accountability. UCLA, Los Angeles governance and social development resource centre. Retrieved from http://www.accountabilityindia.in/article/documentlibrary/482-community-participation-service-delivery-andaccountability on $11^{\text {th }}$ June, 2012.

Cowell, R., \& Murdoch, J. (1999). Land use and the limits to (regional) governance: Some lessons from planning for housing and minerals in England. International Journal of Urban and Regional Research, 23(4), 654-669.

Dahal, D. R. (2004). New social movements in Nepal, The Organisation, 2. 1-14 (June-July).

Dahal, D. R. (2010). Reflection on Leviathan: State and governance in Nepal, Vol. 58, Universitätsbibliothek der Universität Heidelberg.

Dill, B. (2009). The paradoxes of community based participation in Dar es Salaam. Development and Change, 40(4), 717-743.

Escobar, A. (1988). Power and visibility: Development and the invention and management of the Third World, Cultural Anthropology, 3(4), 428-443.

Grindle, M. S. (2007). Good enough governance revisited. Development Policy Review, 25(5), 533-574.

Gaynor, N. \& O'Brien, A. (2011). Because it all begins with talk: Community radio as a vital element in community development. Community Development Journal 47 (3), 436447.

Healey, J. F. (2011). Statistics: A tool for social research. Belmont: Wadsworth Publishing Company.

Halsall, Jamie (2012). Community governance - Where did it all go wrong? Journal of Administration and Governance, 7 (2). $1-8$.

Illing, C., \& Gibson, J. (2007). Rural water service provision by municipalities and CBOs: Performance milestones and KPIs. Water $S A, 30(5), 549-554$.

Khanal, R., (2006). Local Governance in Nepal: Democracy at 
grassroots (First Ed.). Lalitpur: Smriti Books.

Kotz, D. M. (2002). Globalization and neoliberalism. Rethinking Marxism, 14(2), 64-79.

Kim, P. S., \& Moon, M. J. (2003). NGOs as incubator of participative democracy in South Korea: Political, voluntary, and policy participation.InternationalJournal of Public Administration, 26(5), 549-567.

Lewis, D., \& Kanji, N. (2009). Non-governmental organizations and development: New York: Taylor \& Francis.

Malla, Y. (2001). Changing policies and the persistence of patronclient relations in Nepal: stakeholders' responses to changes in forest policies. Environmental History 6(2), 287-307.

McCluskey, M., Stein, S. E., Boyle, M. P., McLeod, D. M. (2009). Community structure and social protest: Influences on newspaper coverage. Mass Communication and Society, 12, 353-371.

Meyer, W. E., S. (2007). Initiating network governance by competition experiences from eighteen German regions. In L. Cheshire, V. Higgins \& G. Lawrence (Eds.), Rural governance: New power relations in rural economies and societies (First ed., pp. 81-97). New York: Routledge Studies in Human Geography.

Murray, C. (2012). Coming apart: The state of white America 19602010. New York: Three Rivers Press.

Oliver, C. (1997). Sustainable competitive advantage: Combining institutional and resource-based views. Strategic Management Journal, 18(9), 697-713.

Olowu, D. (2003). Local institutional and political structures and processes: Recent experience in Africa. Public Administration and Development, 23(1), 41-52.

Ostrom, E., Schroeder, L., \& Wynne, S. (1993). Institutional incentives and sustainable development: Infrastructure policies in perspective. Colorado: Westview Press.

O'Toole, K. (2006). Community governance in rural Victoria: Rethinking grassroots democracy? Rural Society, 16(3), 303-319. 
O'Toole, K., \& Burdess, N. (2004). New community governance in small rural towns: The Australian experience. Journal of Rural Studies, 20(4), 433-443.

Pandit, B. H., Wagley, M. P., Neupane, R. P., \& Adhikary, B. R. (2007). Watershed management and livelihoods: Lessons from Nepal. Journal of Forest and Livelihood, 6(2), 67-75.

Pillora, S., \& McKinlay, P. (2011). Local government and community governance: A literature review (pp. 1-29): Australian centre of excellence for local government.

Ross, K., \& Osborne, S. P. (1999). Making a reality of community governance: Structuring government-voluntary sector relationships at the local level. Public Policy and Administration. 14(2), 49-61.

Roodt, M. (1996). Participatory development: A jargon concept. Johannesburg: International Thomson Publishing.

Ståhlberg, Krister (1997) Hæmeenlinna: Enhancing citizen and community participation, in M. Pröhl (ed.) International strategies and techniques for future local government: Practical Aspects towards innovation and reform. Gütersloh: Bertelsmann Foundation Publishers.

Titeca, K. (2006). Civil society organizations, local governments and political struggles: Formal institutions and informal practices. Paper presented at the Towards MDG Localization in Africa: Options and Experiences:Compendium of the Regional SNV/UNDP/MDP for East and Southern Africa, Uganda 9-11 August 2005, Retrived from http://www. snvworld.org/en/Documents/Towards\%20MDG\%20 Localisation $\% 20 \mathrm{in} \% 20 \mathrm{~A}$ frica $\% 20-\% 20$ Options $\% 20$ and\%20Experiences.pdf, 24th September 2012.

Uphoff, N. (2004). Local communities and institutions: Realizing their potential for integrated rural development. In C.M. Wijayaratna (Ed.), Role of local communities and institutions in integrated rural development, (pp. 63-84): Tokyo, Asian Productivity Organization.

Upreti, B. R., \& Müller-Böker, U. (2010). A decade of armed conflict and livelihood insecurity in Nepal. In B. R. U. \&. U. MüllerBöker (Ed.). Livelihood insecurity and social conflict in Nepal. Kathmandu: Swiss National Centre of Competence 

in Research (NCCR) North-South.

Wallace, A. (2012). Remaking community?: New labour and the governance of poor neighbourhoods. New York: Ashgate Publishing.

WaterAid. (2012). Dang: Drinking water and sanitation profile. Kathmandu: Water Aid Nepal and FedaWATSAN.

Weber, M., Driessen, P. P. J., \& Runhaar, H. A. C., (2011). Drivers of and barriers to shifts in governance: Analysing noise policy in the Netherlands. Journal of Environmental Policy \& Planning, 13(2), 119-137. http://doi.org/10.1080/15239 08X.2011.572657

Zafarullah, H., \& Huque, A. (2001). Public management for good governance: Reforms, regimes, and reality in Bangladesh. International Journal of Public Administration, 24(12), 1379-1403.

Zafarullah, H., \& Huque, A. (2001). Public management for good governance: Reforms, regimes, and reality in Bangladesh. International Journal of Public Administration, 24(12), 1379-1403.

Acharya, Keshav K. Phd is a researcher of University of New England. His main interest areas are governance, service delivery, and community development. He holds MSc in Rural and Regional Development Planning from the Asian Institute of Technology Thailand. Dr. Acharya as a development practitioner worked in different positions and projects of UNDP and other development projects (Nepal, Thailand, and Australia) for more than 15 years. Additionally, he persuaded number of research and development projects in the area of capacity gap assessment of central and local government bodies, impact assessment of community development, and formulation of local government strategic plans and disaster plans. He has written some books, articles and research papers, which are published in peer-reviewed international journals and book chapters.

Email: keshavkacharya@gmail.com 